\title{
Changes of vegetation effects in soil properties in the post-agriculture landscapes (south-eastern Poland)
}

\begin{abstract}
Plant succession is quite a common phenomenon in Poland, especially in agricultural landscapes. At the turn of the 21st century there was a significant increase in the area of fallow lands. That increased the area occupied by ruderal and segetal vegetation. The development of vegetation on post-agricultural lands transforms soils. The aim of this paper is to determine changes in vegetation and soil properties that occur as a result of secondary succession on post-agricultural lands in loess landscapes
\end{abstract}

Keywords

Plant succession $\cdot$ soils $\bullet$ abandoned lands $\bullet$ loess landscape $\bullet$ chemical properties

(c) University of Warsaw - Faculty of Geography and Regional Studies

\author{
Agnieszka Joanna Sosnowska \\ Faculty of Geography and Regional Studies, \\ University of Warsaw, Warsaw, Poland \\ e-mail: a.sosnowsk@@uw.edu.pl \\ Received: 25 March 2018 \\ Accepted: 5 October 2018
}

Introduction

Plant succession is a sequence, or orderly corollary of plant communities, both in space and in time (Falińska 1997). This theory was formulated by Clements (1928) at the beginning of the 20th century, and was significantly developed and refined by other researchers (Trojan 1977; Odum 1982).

According to Clements (1928), plant succession is a change of species combination on an area that was not previously occupied by vegetation (a primary succession), or on an area that was previously settled by vegetation whose structure was demolished or destroyed (a secondary succession). There are three main stages of succession. In the first, a free space appears, which initiates the processes of a primary succession (e.g. dunes) or secondary succession (e.g. arable lands). The second stage is mainly environmental conditions being modified by the growth of vegetation. At this stage, the observed changes appear first and foremost in the chemical and physical properties of soils (Li et al. 2013). The last stage is determined as a final stadium or "climax". The community stabilises, which in certain climatic conditions can take time, and it also expands (eds. Glenn-Lewin et al. 1992).

Plant succession is not only a process of change in species combination, but also one that modifies soil. This is related to a "closing" of the circulation of both matter and energy in the landscape (Richling \& Solon 2011). This is manifested by a clear increase in total biomass, which then decomposes and leads to changes in the geochemical properties of soils (Sosnowska 2012).

Secondary plant succession is a fairly common occurrence in all regions of the world (Kennard 2002; Ruprecht 2005; Cojzer et al. 2014; Derroire 2016; Hahn et al. 2017). It is a consequence of long-term intensive land use and appears both in urban (Gantes et al. 2014) and agricultural areas (Vesterdal et al. 2002). Due to intensifying economic and demographic processes, plant succession phenomenon will certainly increase in the near future (Piussi \& Pettenela 2000).
Ecosystems that have been transformed by humans as a result of intensive agricultural use and then abandoned tend to change towards natural forest or grassland communities. Initially, in the first stage of succession, species of herbaceous (segetal plants) appear (Kinhal \& Parthasarathy 2008; Sojneková \& Chitrý 2015), and over time are displaced by other species, while trees arrive at the end (Prach et al. 2014). In Central Europe, the entry of trees onto fallow lands is a long-term phenomenon. Forest returns to abandoned dunes within about 60 years (Rahmonov 2007), while for post-agricultural lands this may take from 140 to 290 years (Faliński 1991). However, the first tree stands are formed after around 20 years. They are usually composed of pioneer tree species (e.g. silver birch tree) that prepare the soil for the entry of appropriate species (Jõgste at al. 2003; Bijak et al. 2014).

The intensive development of vegetation leads to the transformation of the physical and chemical properties of soils (Kosmas et al. 2000, Harasimiuk 2008, Hall et al. 2017). The mechanisms by which soils are transformed, especially poorly fertile soils, have been quite well established and investigated in the literature (Smal et al. 2004; Sosnowska 2013). Fertile loess soils are rarely abandoned, hence studies relating to these in the literature are fewer, and mainly come from China (Zhang et al. 2012; Li et al. 2013; Wang et al. 2018).

The secondary succession process on agricultural areas in Poland is very common and has been observed for a long time (Szwagrzyk 2004). It can be seen in an increase in the area of abandoned lands, especially at the turn of the 20th century, and Poland therefore seems to be a representative area for conducting research on soil transformation as a result of abandonment. The increase in post-agricultural lands in Poland was caused by: a collapse of the state sector of agriculture; extensive crop production; the diversification of farms in terms of level of development, size and direction of production; and a steep fall in cattle and sheep populations (Węclawowicz et al. 2006). At the 


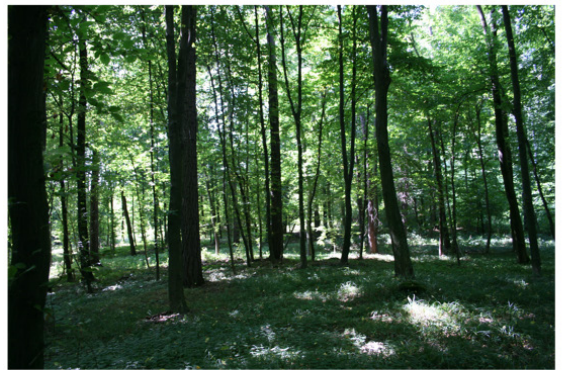
Forest

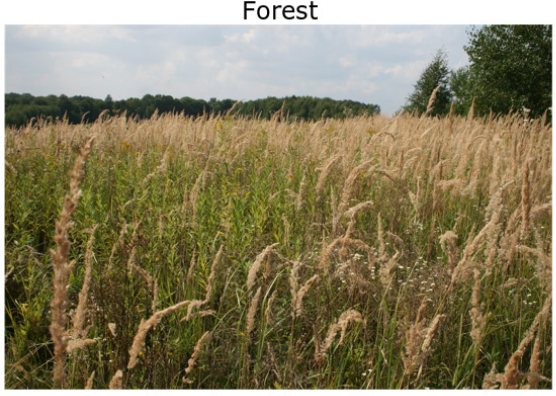

Abandoned land (5 years)

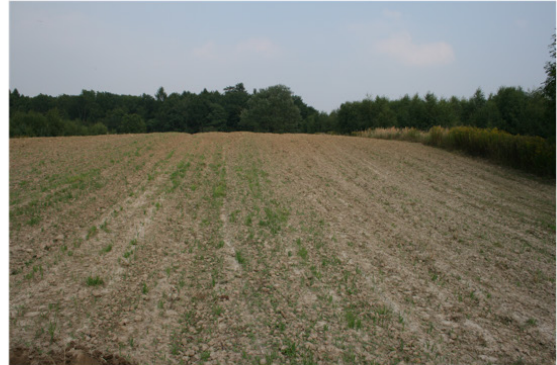

Arable land

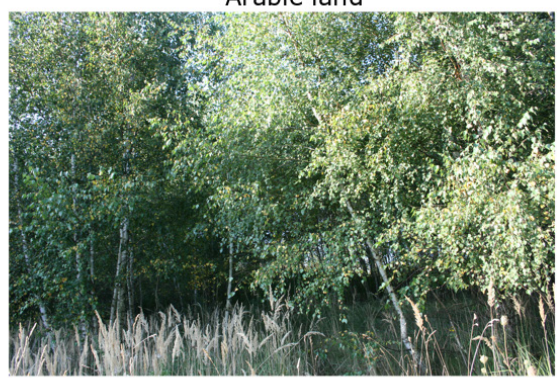

Abandoned land (20 years)

Figure 1. Polygons of different land use. Photo: A.Sosnowska

beginning of the 21st century, abandoned arable lands occupied $1,289,000$ ha, i.e. almost one tenth of Poland's agricultural land (Statistical Yearbook of Agriculture 2010). After Poland's accession to the European Union, a lot of wasteland was re-developed, which contributed to a decline in the area of set-aside and fallow lands. In recent years these leveled out at around 500,000 ha (Statistical Yearbook of Agriculture 2013), but decreased further in 2016 (Statistical Yearbook of Agriculture 2016).

The aim of this article is to determine changes occurring in vegetation - and what impact those changes have on the transformation of the properties of loess soils after arable lands are abandoned. The additional goal is to indicate changes in soils properties as the vegetation develops, and to conclude whether, 20 years after abandonment, soils are more similar to those under forest than those under arable land.

\section{Material and methods}

The research area was located in south-eastern Poland, in the Lublin Upland (Kondracki 2009). This area is east of the Wieprz river valley and the town of Krasnystaw, near the village of Chełmiec. Geologically, it is a hummock of approx. 1,283 ha built mainly of Upper Cretaceous limestone rocks and marls. These rocks are covered with loess of varied thickness (6-12 m) (Jahn 1956). Luvisols and Cambisols (brown soils) dominate here. They cover about $35 \%$ of this region (Turski et al. 1993).

Due to the ages of human activity, the vegetation of this area has been thoroughly transformed. Forest and xerothermic grasslands have been replaced by fields and meadows, and segetal and ruderal plants became dominant. Forest vegetation covers only a few percent of the area, mainly on steep slopes and in gorges (Baran-Zgłobicka et al. 2001).

Four polygons of different land use were selected for detailed research: an arable land, two post-agricultural lands at various stages of succession (five and twenty years after abandonment of agricultural use), and one forest (Fig. 1). All research areas are located very close to each other (Fig. 2).

In each research area, the most frequent plant species were determined based on the Braun-Blanquet method (1951). According to the methodological assumptions, plant species that cover from $75 \%$ to $100 \%$ of the area have been ascribed a frequency of 5 , while those that occur on less than $5 \%$ have been ascribed a value of 1 .

During field works, soil cover was also examined. Twelve soil pits were excavated to a depth of $150-180 \mathrm{~cm}$ - three for each type of land use. All soil pits were located along the line passing through the central part of each research area. The schematic location of soil pits is presented in Fig. 3. Soil samples were taken from all soil horizons, then dried, pulped and sieved in laboratory. Sampling, preparation for laboratory analyses and proper laboratory analyses were carried out in accordance with methodological guidelines (Bednarek et al. 2005; Jahn et al. 2006).

The laboratory analyses of soils include:

- $\quad$ particle-size distribution by sieve (sand), and areometric Cassagrande modified by the Prószyński method (silt and clay),

- the organic carbon content (OCC) by the Tiurin method,

- $\mathrm{pH}$, potentiometrically in $1 \mathrm{~mol} \mathrm{KCl}$ solution using an $\mathrm{MX}$ 300 Mettler Toledo x-mate Pro,

- the content of carbonates by the Scheibler method $\left(\mathrm{CaCO}_{3}\right)$,

- acidic and alkaline element contents by the Kappen method; on their basis, the saturation of the soil sorption complex with alkaline (Vs) and acid (Vh) cations was calculated.

Soil type was determined based on the Polish Soil Classification (2011) and World reference base for soil resources (2015), while the particle-size distribution was determined according to Granular Classification 2008 (annex 3 in Polish Soil Classification).

According to the obtained results, the average values of parameters (Table 3 ) were determined.

\section{Results}

Land cover and vegetation

During the field work, the plant species were determined. The list of the recognised species with a frequency value (1-5) according to the Braun-Blanquet method is presented in Table 1.

Arable land has been cultivated for at least several decades. It belongs to bonitation classes II and IIla (good and medium soils). In the year of this field work, spring barley and winter wheat 


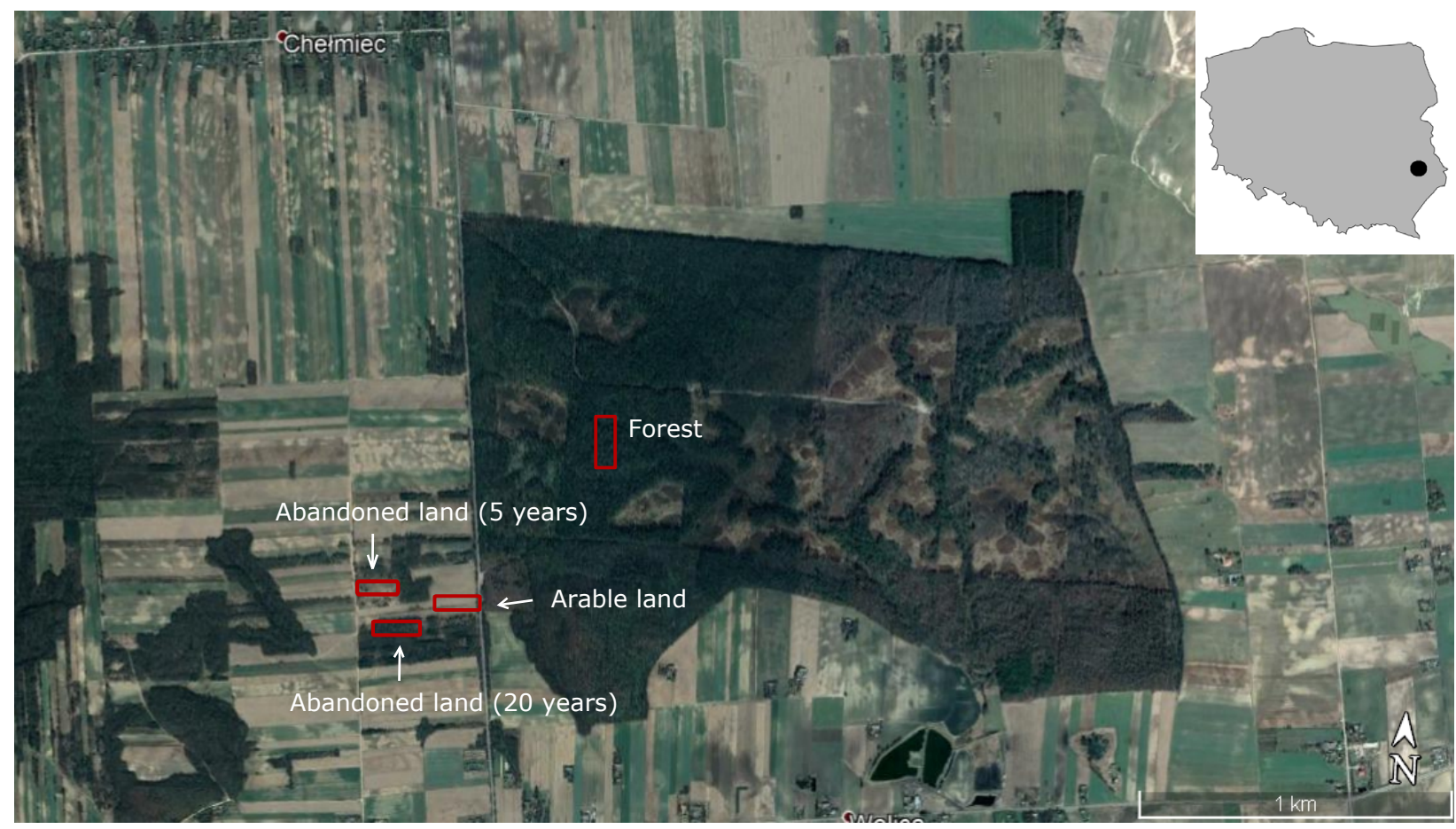

Figure 2. Location of research areas (based on google maps)

soil pit no 1

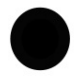

Figure 3. Schematic location of soil pits

were cultivated in this area. No segetal species were found.

The researched post-agricultural land has a large vegetation cover. After five years of abandonment, $90-100 \%$ of the area has been overgrown with grass vegetation. The dominant species is wood small-reed (Calamagrostis epigejos (L.) Roth). The height of the grass in the full vegetation season reaches $1.5-2.0 \mathrm{~m}$. There are also some areas covered with moss, mainly a common redstemmed feathermoss (Pleurozium schreberi (Willd.) Mitten.).

The post-agricultural lands abandoned for twenty years are overgrown by a fifteen-year-old birch stand (Betula pendula Roth) with a cover of $40-50 \%$. The trees are unevenly arranged. They grow in clumps, with surfaces occupied by grassy vegetation in between - mainly wood small-reed (Calamagrostis epigejos (L.) Roth). There is no brushwood layer. The undergrowth is very well-developed, in some places red-stemmed feathermoss (Pleurozium schreberi (Willd.) Mitten) also appears.

The forest research area is covered with 60- to 80-yearold beech tree stand (Fagus sylvatica L.). According to some archival maps, this area has been forested since at least the second half of the 19th century. There is no brushwood in the forest, due to significant shading in summer. The overgrowing, however, is very well developed (about $80-90 \%$ cover). The rich species composition is evident in spring. Asarabacca (Asarum europaeum L.), a sweetscented bedstraw (Galium odoratum (L.) Scop.), and wood anemone (Anemone nemorosa L.) were found, among others.
Table 1. Plant species examined on researched polygons, with frequency (1-5)

\begin{tabular}{|c|c|}
\hline Land use type & Plant species \\
\hline $\begin{array}{c}\text { Abandoned land } \\
\text { ( } 5 \text { years) }\end{array}$ & $\begin{array}{c}\text { Calamagrostis epigejos (L.) Roth }-5 \text {, } \\
\text { Solidago gigantea Aiton }-3 \\
\text { Solidago canadensis L. }-3 \\
\text { Betula pendula Roth }-1\end{array}$ \\
\hline $\begin{array}{l}\text { Abandoned land } \\
\text { (20 years) }\end{array}$ & $\begin{array}{c}\text { Calamagrostis epigejos (L.) Roth }-4 \text {, } \\
\text { Betula pendula Roth }-3, \\
\text { Solidago gigantea Aiton }-2, \\
\text { Solidago canadensis L. }-2, \\
\text { Tanacetum vulgare L. }-2, \\
\text { Achillea millefolium L. }-2, \\
\text { Alnus incana (L.) Moench }-1, \\
\text { Helichrysum arenarium (L.) Moench - } 1 \text {, } \\
\text { Laserpitium prutenicum L. - } 1 .\end{array}$ \\
\hline Forest & $\begin{array}{c}\text { Fagus sylvatica L. }-5, \\
\text { Asarum europaeum L. }-4 \text {, } \\
\text { Galium odoratum (L.) Scop. }-4 \text {, } \\
\text { Anemone nemorosa L. }-3 \text {, } \\
\text { Lysimachia nemorum L. }-3 \text {, } \\
\text { Ranunculus lanuginosus L. }-2 \text {, } \\
\text { Veronica montana L. }-2 \text {, } \\
\text { Carex digitala L. }-2, \\
\text { Larix decidua Mill }-1 \text {, } \\
\text { Betula pendula Roth }-1 \text {. }\end{array}$ \\
\hline
\end{tabular}

\section{Soil profile characteristics}

The examined soils belong to typical luvisols, or typical luvisols with damaged ochric horizon (Polish Soil Classification 2011) or Haplic Luvisols (World reference base for soil resources 2015). They are made of loess. The content of silt fraction $(0.05-0.002$ 
MISCELLANEA GEOGRAPHICA - REGIONAL STUDIES ON DEVELOPMENT

Vol. $23 \cdot$ No. $1 \cdot 2019 \cdot$ pp. 63-70 • ISSN: 2084-6118 • DOI: 10.2478/mgrsd-2018-0032

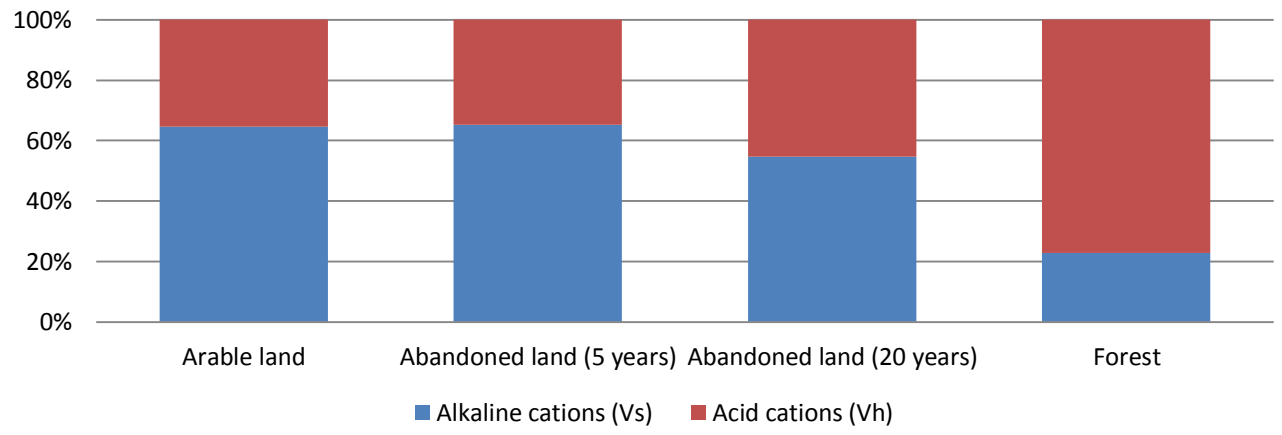

Figure 4. Saturation of soil sorption complex (average from 3 soil pits). Source: own elaboration

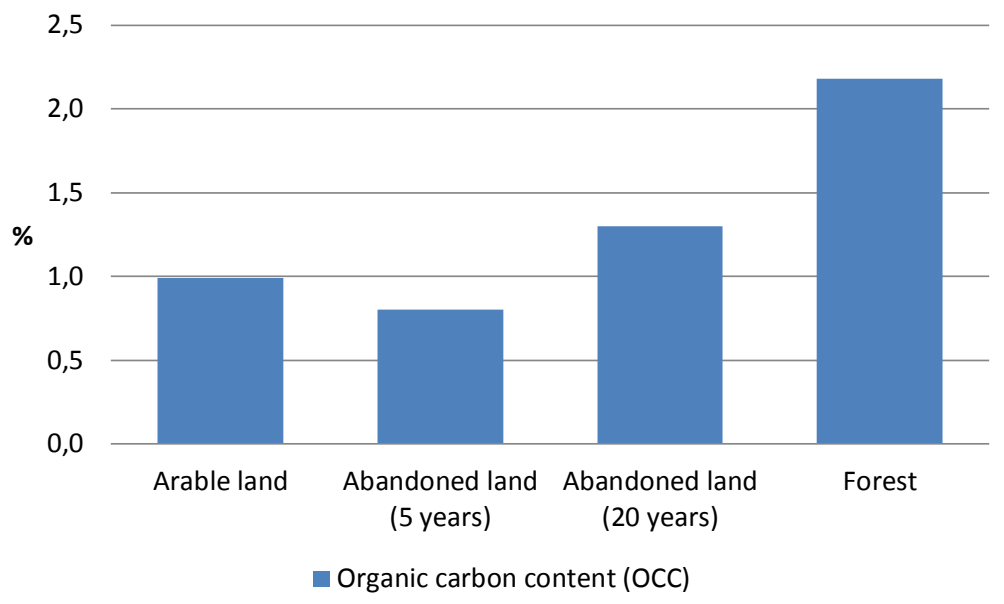

Figure 5. Humus horizons organic carbon content (average result from 3 soil pits). Source: own elaboration

$\mathrm{mm}$ ) ranges from $59 \%$ to $84 \%$ (Table 2 ). There is a significant admixture of clay $(<0.002 \mathrm{~mm})$, the content of which is $16-40 \%$. Usually no sand fraction $(2.00-0.05 \mathrm{~mm})$ occurs, or its content fluctuates in the range $1-2 \%$.

In the arable land soils, no organic horizon nor typical humus horizon were found (Table 2). The humus horizon (Ap) is mixed within the luvic horizon (Et) as a result of deep plowing. The average thickness of this layer is $37 \mathrm{~cm}$. The soil reaction of this layer is acidic ( $\mathrm{pH}$ average 5.30) and higher than in the lower horizon (average 4.32) (Table 3). The average $\mathrm{pH}$ value for the bedrock is 4.29 . No calcium carbonate was found in any horizons, but in the soil sorption complex alkaline ions prevail, from $64.7 \%$ in the top to $86.4 \%$ in lower horizons. The humus horizons contain an average of $0.99 \%$ organic carbon.

In the lands that have been abandoned both for five and for twenty years an ectohumus layer of $1-2 \mathrm{~cm}$ thick was found. It consists of poorly distributed organic matter. There is an old plow layer below it, located within the luvic horizon (Et), with a thickness of $14-23 \mathrm{~cm}$. The level of argilic (Bt) is well developed (about $42-56 \mathrm{~cm}$ ). Solum is usually strongly acidic (on average 4.22-4.28 in horizon A and 4.32-4.41 in horizon B). Carbonates appear in the lower part of the profiles (in bedrock, on average $5.6-6.5 \%)$. The organic carbon content is on average $0.80 \%$ on lands abandoned five years ago and $1.30 \%$ on those abandoned twenty years ago. Similarly to the arable soils, alkaline cations predominate in the sorption complex. But the longer they are set aside, the further their content in the humus horizon decreases (Fig. 4).
Forest soils have a fully developed soil profile, which is characteristic for Haplic Luvisols. The organic horizons are 2-3 $\mathrm{cm}$ thick. The humus horizon's average thickness is $7 \mathrm{~cm}$, the luvic layer is $22 \mathrm{~cm}$ thick on average, and the argilic horizon is very well developed, reaching an average thickness of $82 \mathrm{~cm}$. The $\mathrm{pH}$ value of the humus layer is 3.42 on average, while for argilic layer the value is 3.57 . These are the lowest of the $\mathrm{pH}$ values in the researched areas. In the layer of bedrock the average $\mathrm{pH}$ value is 7.16 , and carbonates $(6.20 \%)$ were also found. By contrast, organic carbon achieves much higher values than in the previously described soils ( $2.18 \%$ on average) (Fig. 5$)$. In the soil sorption complex, acid elements prevail in the humus and luvic horizons $(77.2 \%$ and $62 \%)$. However, in the lower layers alkaline cations dominate.

\section{Discussion}

This paper focuses on the secondary succession of vegetation occurring on post-agricultural lands, as well as on soil transformation resulting from the development of vegetation.

The abandonment of arable land leads to natural plants communities overgrowing its surface already in the first year (Harmer et al. 2001; Wolski 2007). In the initial phase, very expansive species of segetal and ruderal plants spread (Falińska 1997; Lencová \& Prach 2011). In the early stages of succession, the plants' life strategy consists primarily of producing numerous, and easily and widely disseminated seeds, which enables rapid colonisation (Bernadzki 1990). The pioneer species include silver birch (Betula pendula Roth). It appears in dense stands twenty 
Table 2. Particle-size distribution of examined soils. Source: own elaboration

\begin{tabular}{|c|c|c|c|c|c|c|}
\hline Land use type & Soil pit & Soil horizon & $\begin{array}{l}\text { Depth } \\
(\mathrm{cm})\end{array}$ & $\begin{array}{c}\text { Sand } \\
2.00-0.05 \mathrm{~mm}(\%)\end{array}$ & $\begin{array}{c}\text { Silt } \\
\text { 0.05-0.002 mm (\%) }\end{array}$ & $\begin{array}{c}\text { Clay } \\
<0.002 \mathrm{~mm}\end{array}$ \\
\hline \multirow{3}{*}{ Arable land } & no. 1 & $\begin{array}{c}\text { ApEt } \\
\text { Bt } \\
\text { C }\end{array}$ & $\begin{array}{c}0-60 \\
60-135 \\
135-177\end{array}$ & $\begin{array}{l}2 \\
1 \\
1\end{array}$ & $\begin{array}{l}71 \\
59 \\
73\end{array}$ & $\begin{array}{l}27 \\
40 \\
26\end{array}$ \\
\hline & no. 2 & $\begin{array}{c}\text { ApEt } \\
\mathrm{Bt} \\
\mathrm{C}\end{array}$ & $\begin{array}{c}0-25 \\
25-73 \\
73-157\end{array}$ & $\begin{array}{l}0 \\
1 \\
2\end{array}$ & $\begin{array}{l}67 \\
71 \\
67\end{array}$ & $\begin{array}{l}33 \\
28 \\
31\end{array}$ \\
\hline & no. 3 & $\begin{array}{c}\text { ApEt } \\
\mathrm{Bt} \\
\mathrm{Cca}\end{array}$ & $\begin{array}{c}0-36 \\
36-114 \\
114-170\end{array}$ & $\begin{array}{l}1 \\
0 \\
0\end{array}$ & $\begin{array}{l}74 \\
70 \\
84\end{array}$ & $\begin{array}{l}25 \\
30 \\
16\end{array}$ \\
\hline \multirow{3}{*}{$\begin{array}{l}\text { Abandoned land } \\
\text { (5 years) }\end{array}$} & no. 1 & $\begin{array}{c}\mathrm{Ol} \\
\mathrm{ApEt} \\
\mathrm{Bt} \\
\mathrm{BtCca} \\
\mathrm{Cca} \\
\end{array}$ & $\begin{array}{c}1-0 \\
0-25 \\
25-63 \\
63-115 \\
115-182 \\
\end{array}$ & $\begin{array}{l}- \\
1 \\
0 \\
0 \\
1\end{array}$ & $\begin{array}{l}- \\
70 \\
77 \\
77 \\
79 \\
\end{array}$ & $\begin{array}{c}- \\
29 \\
33 \\
33 \\
20 \\
\end{array}$ \\
\hline & no. 2 & $\begin{array}{c}\text { Ol } \\
\text { ApEt } \\
\text { Bt } \\
\text { Cca }\end{array}$ & $\begin{array}{c}1-0 \\
0-23 \\
23-75 \\
75-154\end{array}$ & $\begin{array}{l}- \\
0 \\
0 \\
1\end{array}$ & $\begin{array}{l}- \\
68 \\
78 \\
75\end{array}$ & $\begin{array}{l}- \\
32 \\
22 \\
24\end{array}$ \\
\hline & no. 3 & $\begin{array}{c}\text { Ol } \\
\text { ApEt } \\
\text { Bt } \\
\text { BtC } \\
\text { Cca }\end{array}$ & $\begin{array}{c}1-0 \\
0-23 \\
23-67 \\
67-122 \\
122-154\end{array}$ & $\begin{array}{l}- \\
0 \\
1 \\
0 \\
1\end{array}$ & $\begin{array}{c}- \\
69 \\
65 \\
77 \\
67\end{array}$ & $\begin{array}{c}- \\
31 \\
34 \\
23 \\
32\end{array}$ \\
\hline \multirow{3}{*}{$\begin{array}{c}\text { Abandoned land } \\
\text { (20 years) }\end{array}$} & no. 1 & $\begin{array}{c}\mathrm{Ol} \\
\mathrm{ApEt} \\
\mathrm{Bt} \\
\mathrm{Cca}\end{array}$ & $\begin{array}{c}1-0 \\
0-15 \\
15-100 \\
100-143\end{array}$ & $\begin{array}{l}- \\
0 \\
0 \\
1\end{array}$ & $\begin{array}{l}- \\
76 \\
71 \\
75\end{array}$ & $\begin{array}{l}- \\
24 \\
29 \\
24\end{array}$ \\
\hline & no. 2 & $\begin{array}{c}\mathrm{Ol} \\
\mathrm{ApEt} \\
\mathrm{Bt} \\
\mathrm{BtCca} \\
\mathrm{Cca} \\
\end{array}$ & $\begin{array}{c}2-0 \\
0-20 \\
20-48 \\
48-84 \\
84-156 \\
\end{array}$ & $\begin{array}{l}- \\
0 \\
0 \\
0 \\
0\end{array}$ & $\begin{array}{c}- \\
63 \\
61 \\
72 \\
64 \\
\end{array}$ & $\begin{array}{c}- \\
37 \\
39 \\
28 \\
36 \\
\end{array}$ \\
\hline & no. 3 & $\begin{array}{c}\mathrm{Ol} \\
\mathrm{Ah} \\
\mathrm{Et} \\
\mathrm{Bt} \\
\mathrm{Cca}\end{array}$ & $\begin{array}{c}1-0 \\
0-5 \\
5-28 \\
28-90 \\
90-132\end{array}$ & $\begin{array}{l}- \\
0 \\
0 \\
1 \\
0\end{array}$ & $\begin{array}{c}- \\
70 \\
64 \\
65 \\
80\end{array}$ & $\begin{array}{c}- \\
30 \\
36 \\
34 \\
20\end{array}$ \\
\hline \multirow{3}{*}{ Forest } & no. 1 & $\begin{array}{c}\mathrm{Ol} \\
\mathrm{Ah} \\
\mathrm{Et} \\
\mathrm{Bt} \\
\mathrm{BtCca} \\
\text { Cca }\end{array}$ & $\begin{array}{c}2-0 \\
0-7 \\
7-25 \\
25-85 \\
85-126 \\
126-164\end{array}$ & $\begin{array}{l}- \\
2 \\
1 \\
0 \\
0 \\
4\end{array}$ & $\begin{array}{c}- \\
69 \\
64 \\
60 \\
67 \\
72 \\
\end{array}$ & $\begin{array}{l}- \\
29 \\
35 \\
40 \\
33 \\
24\end{array}$ \\
\hline & no. 2 & $\begin{array}{c}\text { Ol } \\
\mathrm{Ah} \\
\mathrm{Et} \\
\mathrm{Bt} \\
\mathrm{Cca}\end{array}$ & $\begin{array}{c}3-0 \\
0-8 \\
8-35 \\
35-131 \\
131-177\end{array}$ & $\begin{array}{l}- \\
2 \\
0 \\
2 \\
1\end{array}$ & $\begin{array}{c}- \\
72 \\
70 \\
68 \\
80 \\
\end{array}$ & $\begin{array}{c}- \\
26 \\
30 \\
30 \\
19 \\
\end{array}$ \\
\hline & no. 3 & $\begin{array}{c}\mathrm{Ol} \\
\mathrm{Ah} \\
\mathrm{Et} \\
\mathrm{Bt} \\
\mathrm{Cca}\end{array}$ & $\begin{array}{c}2-0 \\
0-7 \\
7-29 \\
29-109 \\
109-151\end{array}$ & $\begin{array}{l}- \\
0 \\
0 \\
0 \\
1\end{array}$ & $\begin{array}{l}- \\
76 \\
71 \\
72 \\
75\end{array}$ & $\begin{array}{c}- \\
25 \\
29 \\
28 \\
24\end{array}$ \\
\hline
\end{tabular}


MISCELLANEA GEOGRAPHICA - REGIONAL STUDIES ON DEVELOPMENT

Vol. 23 • No. 1 • 2019 • pp. 63-70 • ISSN: 2084-6118 • DOI: 10.2478/mgrsd-2018-0032

Table 3: Soil properties (own elaboration, average result from 3 soil pits). Source: own elaboration

\begin{tabular}{|c|c|c|c|c|c|c|}
\hline Land use type & Horizon & OCC (\%) & $\mathbf{p H}$ & Carbonates (\%) & Vs (\%) & Vh (\%) \\
\hline \multirow{3}{*}{ Arable land } & $\mathrm{ApEt}$ & 0.99 & 5.30 & - & 64.7 & 35.3 \\
& $\mathrm{Bt}$ & - & 4.32 & - & 80.7 & 19.3 \\
& $\mathrm{C}$ & - & 4.29 & - & 86.4 & 13.6 \\
\hline \multirow{2}{*}{ Abandoned land } & $\mathrm{ApEt}$ & 0.80 & 4.28 & - & 65.2 & 34.8 \\
(5 years) & $\mathrm{Bt}$ & - & 4.32 & - & 83.3 & 16.7 \\
& $\mathrm{Cca}$ & - & 7.08 & 6.50 & 100.0 & 0.0 \\
\hline \multirow{2}{*}{ Abandoned land } & $\mathrm{ApEt}$ & 1.3 & 4.22 & - & 56.8 & 43.2 \\
(20 years) & $\mathrm{Bt}$ & - & 4.44 & - & 86.3 & 13.7 \\
& $\mathrm{Cca}$ & - & 6.48 & 5.60 & 94.3 & 5.7 \\
\hline \multirow{4}{*}{ Forest } & $\mathrm{Ah}$ & 2.18 & 3.42 & - & 22.8 & 77.2 \\
& $\mathrm{Et}$ & - & 3.57 & - & 38.0 & 62.0 \\
& $\mathrm{Bt}$ & - & 4.11 & - & 66.0 & 34.0 \\
& $\mathrm{Cca}$ & - & 7.16 & 6.20 & 100.0 & 0.0 \\
\hline
\end{tabular}

years after abandonment (Bernadzki \& Kowalski 1983; Hynynen at al. 2010). The roots of the birch can also penetrate through the plow sole, leading to a relatively quick improvement in soil conditions (Harasimiuk 2013).

The obtained results are consistent with other researchers' described above. The polygons where the research work was carried out are in various stages of secondary succession. Arable land is devoid of natural vegetation and subject to strong anthropopressure. In this area, there is no natural development of vegetation. Both types of post-agricultural lands are in the second phase of succession. Despite the fact that a compact forest grows on post-agricultural lands abandoned twenty years ago, the tree species (pioneers) that build it can be considered temporary.

The development of vegetation contributes to the growth of biomass, which undergoes slow decomposition, mainly by two groups of microorganisms: fungi and bacteria (Richards 1979). In arable and post-agricultural soils, cellulose that is a product of herbaceous plants' decomposition is further decomposed, and bacteria are responsible for its distribution. Meanwhile, in woodlands it is lignin that is to be decomposed, and fungi are responsible (Tuszyński 1990; Berg 2000). Microbes play a key role in the carbon cycle and the nutrient cycle. A well-formed soil fauna needs 20-45 years after abandonment to develop (Szujecki 1996). As the organic carbon content in post-agricultural soils decreases in the first years of subsidence and then grows, it can be concluded that the soil fauna syndrome is not yet fully formed. Twenty years of abandonment is too short a time to fully develop the appropriate microbial communities, hence the slow decomposition of biomass (Drewnik et al. 2010). Based on the research, it was found that after five years of abandonment the ectohumus level is about $1-2 \mathrm{~cm}$ thick and maintains this volume in the following years.

Long-term, intensive mechanised soil cultivation leads to the mixing of upper soil levels and the production of a plow layer. The top horizons are usually very compact, with limited biological activity (Szujecki 1996), while fertilisation of arable land increases the $\mathrm{pH}$ value (Stojek 2005), thus changing the chemical properties of soils (ed. Gorzelak 1999). It was discovered during the research that plant succession leads to the transformation of soil profiles, although this phenomenon is much slower than the change in land cover. Post-agricultural soils are characterised by features that are similar to arable soils in terms of the construction of soil profiles: there is not the fully developed humus level that is characteristic for forest soils.

Abandonment also affects the chemical properties of soils, especially organic carbon content. After five years, a slight decline was recorded, and after twenty years an increase. A decrease as a result of abandonment was found in studies by Strączyńska \& Zawieja (2001) and Sosnowska (2013). According to Łętowska \& Strączyńska (2001), the decline appears only in the initial phase of abandonment, and after 10 years a slow increase is observed. Żukowska et al. (2007) suggest that the decrease in organic carbon content in post-agricultural soils may be the result of long-term, extensive tillage.

Change in $\mathrm{pH}$ value is one of the characteristics of transformations in soils that is most commonly used in research (Ritter et al. 2003). This is a consequence of this parameter's significant sensitivity to changes. It was found in the research that the abandonment of agricultural use and the development of natural vegetation lead to a drop in the $\mathrm{pH}$ value of postagricultural soils. The results obtained are consistent with the data provided by other authors (Kosmas et al. 2000; Smal et al. 2004; Harasimiuk 2008).

As a result of the decomposition of organic matter to the soil, nutrients are released that affect the properties of the sorption complex. The percentage of ions in the sorption complex varies greatly depending on land use. Organic and mineral fertilisers are supplied to arable soils, which results in an increase in the saturation with alkaline cations (Wang et al. 2001). In the present research, acid cations were predominant in forest soils, while alkaline cations predominated in the agricultural soils. Abandonment of arable lands affects the change of proportions, leading to an increase in acid nutrients in the sorption complex. The increase in saturation with acid cations has been also confirmed by Łętowska and Strączyńska (2001), Strączyńska and Zawieja (2001), and Braun (2011). In turn, Miklaszewski (1990) observed a decrease in acidity in set-aside soils. Changes in saturation of the sorption complex are relatively quick although, according to Ritter et al. (2003), after 30 years the post-agricultural soils are still closer to agricultural soils than to forest soils. The authors also emphasise the slight impact of the vegetation type (deciduous or coniferous species) on the rate of change, emphasising the importance of the method and intensity of past management.

\section{Conclusions}

It can be concluded from the research that plant succession on post-agricultural lands in loess landscapes occurs relatively quickly, starting immediately after abandonment. After just five years, the vegetation covers about $90 \%$ of the area. A welldeveloped woodland develops after more-or-less twenty years, and is characterised by the pioneer species (silver birch) that it comprises. 
As a result of decomposing vegetation on post-agricultural land, an ectohumus $(\mathrm{O})$ layer is formed - something that does not occur in arable land soils. It usually consists of poorly or medium distributed organic matter.

Post-agricultural soils have a profile layout similar to that occurring in arable soils. The humus level (Ap) is mixed with the underlying level. Clear changes in post-agricultural soil profiles are observed after twenty years of abandonment and are characterised by organic horizon development (O).

Decomposing organic matter affects soil properties. The fastest-occurring changes are seen in the drop in $\mathrm{pH}$ value. Abandonment also leads to a slow increase in organic carbon content and saturation of acid cations in the soil sorption complex.

\section{References}

Baran-Zgłobicka, E, Harasimiuk, M \& Zgłobicki, W 2001, 'Współczesne przemiany krajobrazów rolniczych wyżyn lessowych Polski Południowo-Wschodniej' (Present-day changes of agricultural landscapes of loess uplands of south-east Poland), Problemy Ekologii Krajobrazu, vol. 10, pp. 269-275.

Bednarek, R, Dziadowiec, H, Pokojska, U \& Prusinkiewicz, Z 2005, Badania ekologiczno-gleboznawcze (Ecological and pedological research), Wyd. Naukowe PWN, Warsaw.

Berg, B 2000, 'Litter decomposition and organic matter turnover in northern forest soils', Forest Ecology and Management, vol. 133, pp. 13-22, DOI 10.1016/S0378-1127(99)00294-7.

Bernadzki, E 1990, 'Koncepcja hodowli lasu na gruntach porolnych' (Concepts of silviculture on post-agricultural lands), Sylwan, vol. 134, pp. 51-59.

Bernadzki, E \& Kowalski, M 1983, 'Brzoza na gruntach porolnych' (Birch tree on abandoned lands), Sylwan, vol. 12, pp. 33-42.

Bijak, S, Bronisz K, Szydłowska, P \& Wojtan, R 2014, 'Wpływ jakości siedliska na dynamikę wydzielania brzozy na gruntach porolnych' (Effect of site quality on self-thinning dynamics in silver birch stands on abandoned farmlands), Sylwan, vol. 158, issue 6, pp. 423-430.

Braun, B 2011, 'Changes in soils used for agriculture and westland in the Gałęzowo-Niepoględzie catena (in Bytów region, NW Poland)', Problemy Ekologii Krajobrazu, vol. 30, pp. 263-366.

Braun-Blanquet, J 1951, Pflanzensozologie, Springer-Verlag, Vien.

Clements, FE 1928, Plant succession and indicators, H.W. Wilson, New York.

Cojzer, M, Diaci, J \& Brus, R 2014, 'Tending of young forests in secondary succession on abandoned agricultural lands: An experimental study', Forest, vol. 5, pp. 2658-2678. DOI $10.3390 / 55112658$.

Derroire, G 2016, Secondary succession in tropical dry forests, Acta Universitatis Agriculturae Sueciae, Bangor \& Alnarp.

Drewnik, M, Kacprzak, A \& Maziarka, N 2010, 'Właściwości gleb porolnych na obszarze dawnej wsi Caryńskie' (Characteristics of post-agricultural soils in the former village of Carynskie), Roczniki Bieszczadzkie, vol. 18, pp. 205-216.

Falińska, K 1997, Ekologia roślin (Plant ecology), Wyd. Naukowe PWN, Warszawa, Poland.

Faliński, JB 1991, 'Procesy ekologiczne w zbiorowiskach leśnych' (Ecological processes in forest communities), Phytocoenosis, vol. 3, pp. 17-41.

Gantes, P, Falco, LB, Coviella, C \& Sanchez Caro, A 2014, 'Plant secondary succession age-related changes in landfills', Urban ecosystems, vol. 17, no. 1, pp. 1209-1218.

Glenn-Lewin, DC, Peet, RK \& Veblen, TT (eds) 1992, Plant succession. Theory and prediction, Chapman \& Hall, London.

Gorzelak, A (ed.) 1999, Zalesianie gruntów porolnych (Afforestation of post-agricultural lands), IBL, Warsaw.

Hahn, C, Michalski, SG, Fischer, M \& Durka, W 2017, 'Genetic diversity and differentiation follow secondary succession in a multi-species study on woody plants from subtropical China', Journal of Plant Ecology, vol. 10, no. 1, pp. 213-221, DOI 10.1093/jpe/rtw054.

Van Hall, RL, Cammeraat, LH, Keesstra, SD \& Zorn, M 2017, 'Impact of secondary vegetation succession on soil quality in a humid Mediterranean landscape', Catena, vol. 149, pp. 836-843. DOI 10.1016/j.catena.2016.05.021.

Harasimiuk, A 2008, 'Soils and chemical cycling of elements after land use changes (case studies)', Miscellanea Geographica, vol. 13, pp. 145-151.

Harasimiuk, A2013, Funkcjonowanie krajobrazówoligotroficznych (Functioning of oligotrophic landscapes), WUW, Warsaw.

Harmer, R, Peterken, G, Kerr, G \& Poulton, P 2001, 'Vegetation changes during 100 years of development of two secondary woodlands on abandoned arable land', Biological Conservation, vol. 101, no. 3, pp. 291-304, DOI 10.1016/ S0006-3207(01)00072-6.

Hynynen, J, Niemistö, P, Viherä-Aarnio, A, Brunner, A, Hein, S, \& Velling, P 2010, 'Silviculture of birch (Betula pendula Roth and Betula pubescens Ehrh.) in northern Europe', Forestry, vol. 83, no. 1, pp. 103-119, DOI 10.1093/forestry/cpp035.

Jahn, A 1956, Wyżyna Lubelska. Rzeźba i czwartorzęd (Lubelska Upland. Relief and Quaternary), PWN, Warsaw.

Jahn, R, Blume, HP, Asio, VB, Spaargaren, O \& Schad, P 2006, Guidelines for Soil Description, Food and Agriculture Organization of the United Nations, Rome.

Jõgiste, K, Vares, A \& Sendrós, M 2003, 'Restoration of former agricultural fields in Estonia: comparative growth of planted and naturally regenerated birch', Forestry, vol. 78, pp. 209219.

Kennard, DK 2002, 'Secondary forest succession in a tropical dry forest: patterns of development across a 50-year chronosequence in lowland Bolivia', Journal of Tropical Ecology, vol. 18, pp. 53-66, DOI 10.1017/ S0266467402002031.

Kinhal, V \& Parthasarathy, N 2008, 'Secondary succession and resource use in tropical fallows; A case study from the Coromandel Coast of South India', Land Degradation and Development, vol. 19, issue 6, pp. 646-662.

Kondracki, J 2009, Geografia regionalna Polski (Polish regional geography), Wyd. Naukowe PWN, Warsaw.

Kosmas, C, Gerontidis, S \& Marathianou, M, 2000, 'The effect of land use change on soils and vegetation over various lithological formations on Lesvos (Greece)', Catena, vol. 40, pp. 51-68.

Lencová, K \& Prach, K 2011, 'Restoration of hay meadows on ex-arable land: commercial seed mixtures vs. spontaneous succession', Grass and Forage Science, vol. 66, no. 2, pp. 265-271, DOI 10.1111/j.1365-2494.2011.00786.x.

Li, Y, Yang, F, Ou, Y, Zhang, D, Liu, J, Chu, G, Zhang, Y, Otieno, D \& Zhou, G 2013, 'Changes in forest soil properties in different successional stages in lower tropical China', PLoS One, vol. 8, no. 11, DOI 10.1371/journal.pone.0081359.

Li, JJ, Zheng, YM, Yan, JX, Li, HJ \& He JZ 2013, 'Succession of plant and soil microbial communities with restoration of 
abandoned land in the Loess Plateau, China', Journal of Soil and Sediments, vol. 13, pp. 760-769.

Łętowska, A \& Strączyńska, S 2001, 'Wybrane właściwości fizykochemiczne i chemiczne gleb odłogowanych i użytkowanych rolniczo' (Selected physicochemical and chemical properties of abandoned and arable lands), Zeszyty Problemowe Postępów Nauk Rolniczych, vol. 478, pp. 241-248.

Miklaszewski, S 1990, 'Wpływ różnych sposobów użytkowania ornej gleby piaszczystej na jej chemiczne i biologiczne właściwości' (The impact of different use of arable sandy soils on chemical and biological properties), Zeszyty Problemowe Postępów Nauk Rolniczych, vol. 376, pp. 39-45.

Odum, EP 1982, Podstawy Ekologii (Basics of ecology), PWRiL, Warsaw.

Piussi, P \& Pettenella, D 2000, Spontaneous afforestation of fallows in Italy, EFI Proceedings, vol. 35, pp. 151-163.

Polish Soil Classification 2011, Soil Science Annual, vol. 62, no. 2, pp. 1-195.

Prach, K, Rehounková, K, Lencová, K, Jírová, A, Konvalinková, P, Mudrák, O, Študent, V, Vanéćek, Z, Tichý, L, Petŕík, P, Šmilauer, P \& Pyšek, P 2014, 'Vegetation succession in restoration of disturbed sites in Central Europe: the direction of succession and species richness across 19 seres', Applied Vegetation Science vol. 17, pp. 193-200, DOI 10.1111/avsc. 12064.

Rahmonov, O 2007, Relacje między roślinnością i glebą w inicjalnej fazie sukcesji na obszarach piaszczystych (Relations between plants and soils in the initialized stage of succession on sandy areas), Wydawnictwo UŚ, Katowice.

Richards, BN 1979, Wstęp do ekologii gleby (Introduction to soil ecology), PWN, Warsaw.

Richling, A \& Solon, J 2011, Ekologia Krajobrazu (Landscape ecology), Wyd. Naukowe PWN, Warsaw.

Ritter, E, Vesterdal, L \& Gundersen, P 2003, 'Changes in soil properties after afforestation of former intensively managed soils with oak and Norway spruce', Plant and Soil, vol. 249, no. 2, pp. 319-330.

Ruprecht, E 2005, 'Secondary succession in old-fields in the Transylvanian Lowland (Romania)', Preslia, vol. 77, pp. 145-157.

Statistical Yearbook of Agriculture 2010, GUS. Available from: $<$ www.stat.gov.pl>. [10 May 2011].

Statistical Yearbook of Agriculture 2013, GUS. Available from: <www.stat.gov.pl>. [24 October 2013].

Statistical Yearbook of Agriculture 2016, GUS. Available from: $<$ www.stat.gov.pl>. [25 January 2018].

Smal, H, Ligęza, S \& Olszewska, M 2004, 'Wpływ zalesiania piaszczystych gleb porolnych na jakość materii organicznej i skład chemiczny roztworu glebowego' (The effect of afforestation of sandy post-arable soils on the quality of organic matter and chemical composition of soil solution), Soil Science Annual., vol. 55, no. 4, pp. 139-148.

Sojneková, M \& Chitrý, M 2015, 'From arable land to species-rich semi-natural grasslands: Succession in abandoned fields in a dry region of central Europe', Ecological Engineering, vol. 77, pp. 373-381.

Sosnowska, A 2012, 'Land use change impact on soil organic matter. Loess landscape case study', Miscellanea Geographica, vol. 16, no. 2, pp. 11-15.

Sosnowska, A 2013, 'Geochemiczne przekształcenia krajobrazu pod wpływem zmian użytkowania ziemi (na przykładzie okolic Stanisławowa)' (Geochemical transformation of landscape influenced by land use changes (Stanisławów area case study)), Problemy Ekologii Krajobrazu, vol. 33, pp. 145-151.

Stojek, B 2005, 'Zmiany właściwości chemicznych i fizykochemicznych w glebach użytkowanych rolniczo' (Changes of chemical and physicochemical properties of soils under agricultural utilization', Prace $i$ Studia Geograficzne, vol. 36, pp. 97-106.

Strączyńska, S \& Zawieja, J 2001, 'Zmiana fitocenozy w niektórych właściwości gleby pod wpływem jej wieloletniego odłogowania' (Change of phytocoenosis in some of soil properties under the influence of many years' set aside), Zeszyty Problemowe Postępów Nauk Rolniczych., vol. 478, pp. 327-333.

Szujecki, A 1996, 'Ekologiczne aspekty odtwarzania lasu na glebach porolnych' (Ecological aspects of forest regeneration on post-agricultural soils), Prace IBL, vol. 27, pp. 47-55.

Szwagrzyk, J 2004, 'Sukcesja leśna na gruntach porolnych; stan obecny, prognozy i wątpliwości' (Forest succession on abandoned farmland; current estimates, forecasts and uncertainties), Sylwan, vol. 4, pp. 53-59.

Trojan, P 1977, Ekologia ogólna (General ecology), PWN, Warsaw.

Turski, R, Uziak, S \& Zawadzki, S 1993, Środowisko przyrodnicze Lubelszczyzny. Gleby (Natural environment of the Lublin region. Soils), Lubelskie Towarzystwo Naukowe, Lublin.

Tuszyński, M 1990, 'Właściwości gleb porolnych a gospodarka leśna' (Properties of post-agricultural soils and forest management), Sylwan, vol. 134, pp. 41-50.

Wang, J, Fu, B, Qiu, Y \& Chen, L 2001, 'Soil nutrients in relation to land use and landscape position in the semi-arid small catchment on the loess plateau in China', Journal of Arid Environments, vol. 48, pp. 537-550.

Wang, H, Zhang, G, L, N, Zhang, B \& Yang, H 2018, 'Soil erodibility influenced by natural restoration time of abandoned farmland on the Loess Plateau of China', Geoderma, vol. 325, pp. 18-27.

Węcławowicz, G, Bański, J, Degórski, M, Komornicki, T, Korcelli, P \& Sleszyński, P 2006, Przestrzenne zagospodarowanie Polski na początku XXI wieku (Spatial organization of Poland at the beginning of the 21th century), IGiPZ PAN, vol. 6, Warsaw.

Wolski, J 2007, Przekształcenia krajobrazu wiejskiego Bieszczadów Wysokich w ciągu ostatnich 150 lat (Transformations of the High Bieszczady Mountains rural landscape during last 150 years), Prace Geograficzne, vol. 214, IGiPZ PAN, Warsaw.

World reference base for soil resources 2015, World Soil Resources Reports, vol. 106, Rome.

Vesterdal, L, Ritter, E \& Gundersen, P, 2002, 'Change in soil organic carbon following afforestation of former arable lands', Forest Ecology and Management, vol. 169, pp. 137-147.

Zhang, C, Liu, G, Xue, S \& Zhang, C 2012, 'Rhizosphere soil microbial properties on abandoned croplands in the Loess Plateau, China during vegetation succession', European Journal of Soil Biology, vol. 50, pp. 127-136.

Żukowska, G, Flis-Bujak, M, Baran, S \& Wójcikowska-Kapusta, A 2007, 'Wpływ odłogowania na zawartość i jakość substancji organicznej gleb płowych' (The influence of soil lying fallow on the quantity and quality of organic matter in albic luvisols), Zeszyty Problemowe Postępów Nauk Rolniczych, vol. 270, pp. 865-871. 